\author{
Anastasiya Niakrasava \\ nasta.niakrasava@gmail.com \\ Instytut Muzykologii \\ Wydział Historyczny \\ Uniwersytet Warszawski
}

\title{
Niektóre aspekty tradycyjnej kultury muzycznej mniejszości polskiej na Grodzieńszczyźnie
}

\author{
Properties of the Traditional Musical Culture \\ of the Polish Minority in the Grodno Region
}

\begin{abstract}
Streszczenie: Artykuł jest poświęcony zagadnieniom tradycyjnej kultury muzycznej Polaków mieszkających w zachodniej części Republiki Białorusi, na Grodzieńszczyźnie. Na podstawie analizy zarejestrowanego w trakcie własnych badań terenowych repertuaru, autorka wyróżnia najważniejsze jego cechy muzyczne. Kultura muzyczna badanej społeczności zostaje ujęta z perspektywy repertuaru pamiętanego oraz obecnie praktykowanego. Część repertuaru tradycyjnego wraz z jej depozytariuszami odchodzi do świata minionego, z kolei otaczająca rzeczywistość warunkuje współczesne funkcjonowanie kultury muzycznej oraz formy jej prezentacji. Wyniki ankiety dźwiękowej oraz przeprowadzonych wywiadów etnograficznych posłużyły próbie opisania obrazu własnej kultury, funkcjonującej w świadomości białoruskich Polaków.
\end{abstract}

Słowa klucze: mniejszość polska, Grodzieńszczyzna, Białoruś, pieśni, folklor

\begin{abstract}
Summary: The article is devoted to the issues of the traditional musical culture of Poles living in the western part of the Republic of Belarus, in Grodno region. Based on the analysis of the repertoire recorded during her own field research, the author distinguishes the most important of her musical characteristics. The musical culture of the studied community is captured from the perspective of the remembered repertoire and currently practiced. Part of the traditional repertoire with its depositaries goes to the world of the past, while the surrounding reality determines the functioning of the musical culture and the forms of its presentation.
\end{abstract}

Key words: Polish Minority, Grodno region, Belarus, songs, folklore

Translated by Author

Niniejszy artyku1 ${ }^{1}$ poświęcony jest tradycyjnej kulturze muzycznej białoruskich Polaków w kontekście wyników badań nad etnomuzyczną świadomością badanej grupy². Podstawą stały się badania prowadzone przeze mnie w rejonie grodzieńskim w latach

\footnotetext{
${ }^{1}$ Artykuł powstał na podstawie pracy magisterskiej autorki. Zob.: Niakrasava 2015a. Nagrany w terenie repertuar muzyczny jest dostępny na płycie CD dołączonej do pracy.

${ }^{2}$ Związkom repertuaru muzycznego i świadomości (też samoświadomości) społeczności na Grodzieńszczyźnie poświęcone są prace Renaty Banasińskiej (1998) oraz Doroty Frasunkiewicz (1994). W szerszej
} 
2013-2014 wśród muzyków i ludowych śpiewaków, określających siebie jako Polacy3. W ramach badań zostały przeprowadzone wywiady etnograficzne, wykorzystano także metodę ankiet dźwiękowych.

Według ostatniego spisu ludności przeprowadzonego na Białorusi (2009 r.) polską narodowość zadeklarowało 294549 osób, co stanowi 3,1 proc. ogółu społeczeństwa (NKSRB 2009). Porównując dane statystyczne z lat 1989, 1999 i 2009 widać, że liczba deklarujących narodowość polską zmniejszyła się prawie o jedną czwartą na obszarze całego kraju (Eberhardt 1998: 50-58; Gawin 2000: 193; NKSRB 2009). Warto jednak pamiętać, że grupa osób posiadająca poczucie polskiej tożsamości może być większa, m.in. w przypadku podwójnego pochodzenia, np. polsko-białoruskiego, cenzus pozostawiał do wyboru tylko jedną $\mathrm{z}$ tych narodowości. Zatem grupa widoczna w wynikach spisu to osoby o silnie ugruntowanej niebiałoruskiej (tu: polskiej) tożsamości narodowej. Skupiska Polaków koncentrują się w północno-zachodniej części kraju, przy granicy z Polską i Litwą. Mniejszość polska w obwodzie grodzieńskim, czyli na Grodzieńszczyźnie, liczy 230810 osób, z których 140367 mieszka w miastach (tylko w Grodnie 64642 Polaków), a 90443 pochodzi z terenów wiejskich (NKSRB 2009).

W niektórych rejonach Grodzieńszczyzny Polacy są grupą dominującą - jak na przykład w rejonie werenowskim, gdzie ich liczba wynosi 24615 osób, co stanowi 80,8 proc. ogółu mieszkańców. W pozostałych rejonach Polacy również stanowią liczącą się mniejszość narodową (zob.: NKSRB 2009). Rejon grodzieński (wraz z Grodnem) jest szósty na Białorusi pod względem odsetka zamieszkującej go ludności polskiej 21,7 proc. Jednakże jest to rejon o najwyższej liczbie mieszkańców deklarujących polską narodowość (82 965 osób, zgodnie z NKSRB 2009).

W rejonie grodzieńskim funkcjonuje 26 instytucji kulturalnych, np. domy i centra kultury4 , przy których działa 2410 artystów amatorów, będących członkami zespołów bądź występujących jako soliści. 18 zespołów (wokalno-instrumentalnych, wokalnych, teatralnych, tanecznych, instrumentalnych) rejonu grodzieńskiego nosi tytuły „,narodowy” (11), „wzorowy” (5) oraz „zasłużony” (2), które przydzielane są przez specjalne komisje eksperckie za całokształt działalności. Całą sferą kultury zajmuje się Oddział

perspektywie geograficznej został opisany folklor Polaków na Wileńszczyźnie i częściowo Białorusi w pracach Tomasza Nowaka (2006) i Gustawa Juzali (2006).

${ }^{3}$ Ze względu na przedstawienie wybranego tematu, pomijam w artykule opis kontekstu społeczno-historycznego. Kwestie tożsamościowe (w ujęciu emicznym) mające wpływ na znajomość i postrzeganie repertuaru muzycznego przez badaną grupę zostały opisane w dalszej części artykułu. Ważnymi dla zrozumienia innych aspektów funkcjonowania grupy Polaków na Białorusi są prace Iwony Kabzińskiej $(1999,2009)$, Anny Engelking (1996a, 1996b, 2004), Ewy Golachowskiej (2012).

${ }^{4}$ Informacja zaczerpnięta z dokumentów Rejonowego Centrum Metodycznego Twórczości Ludowej i Pracy Kulturowo-Oświatowej w Grodnie. 
Pracy Ideologicznej, Kultury oraz do Spraw Młodzieży Grodzieńskiego Rejonowego Komitetu Wykonawczego.

W całym obwodzie grodzieńskim cyklicznie (raz na rok albo na dwa lata) organizowanych jest 15 festiwali. Wśród nich należałoby przede wszystkim wymienić Republikański Festiwal Kultur Narodowych ${ }^{5}$, Obwodowy Festiwal Tańca „Grodzieńskie koronki”, , Obwodowy Festiwal Folkloru Regionalnego Poniemnia życiodajne źródła ${ }^{7}$ oraz Regionalny Festiwal Artystyczne spotkania Grodno - Białystok ${ }^{8}$. Oprócz wydarzeń muzycznych odbywają się inne uroczystości, np. dni wsi, podczas których mają okazję zaprezentować się lokalni twórcy.

Działalność instytucji kulturalnych, a zwłaszcza organizowane przez nie festiwale i konkursy muzyczne, tworzą platformę do kształtowania oraz prezentowania twórczości zespołów muzycznych oraz indywidualnych twórców ludowych. Scena jednak nie wyczerpuje wszystkich zasobów muzycznych ludności zamieszkującej tereny Grodzieńszczyzny, wielu wiejskich muzykantów pozostaje jeszcze „nieodkrytych”.

W ramach badań nad etnomuzyczną świadomością mniejszości polskiej na Białorusi, w latach 2013-2014 przeprowadziłam ok. 20 wywiadów z kierownikami zespołów muzycznych, śpiewakami i muzykantami ludowymi, zarówno tymi, którzy występowali na scenie, jak i tymi, którzy wykonywali swój zawód muzykanta/śpiewaka wyłącznie w terenie.

Wywiady i sesje nagraniowe przeprowadzono przede wszystkim w czterech różnej wielkości miejscowościach: agromiasteczku Odelsk, wsi Kwasówka, osiedlu typu miejskiego Sopoćkinie oraz stolicy obwodu - Grodnie. Pojedynczych nagrań dokonano także we wsiach: Hoża, Wielka Żornowka, Indura oraz na terenie osiedla Fabryczny niedaleko Grodna. Wybór miejscowości był podyktowany obecnością i możliwościami zaaranżowania spotkań z ludowymi muzykantami i śpiewakami.

Rozmówcami były niemal wyłącznie osoby deklarujące się jako Polacy, w wyjątkowych przypadkach - o niepolskiej narodowości, posiadające wiedzę na temat polskiej

\footnotetext{
${ }^{5}$ Republikański Festiwal Kultur Narodowych odbywa się raz na dwa lata w Grodnie. W 2018 r. odbyła się XII. edycja festiwalu, organizatorem której był Grodzieński Komitet Wykonawczy.

${ }^{6}$ Festiwal Tańca „Grodzieńskie koronki” od 1996 r. odbywa się w Grodnie raz na dwa lata.

${ }^{7}$ Organizatorami festiwalu Poniemnia życiodajne źródła (Paniamonnia żywatwornyja krynicy) są Oddział Pracy Ideologicznej, Kultury oraz do Spraw Młodzieży Grodzieńskiego Rejonowego Komitetu Wykonawczego, a także Rejonowe Centrum Metodyczne Twórczości Ludowej i Pracy Kulturowo-Oświatowej w Grodnie. Festiwal ma trzyetapową strukturę konkursową: pierwszy etap - to przeglądy twórczości ludowej prowadzonej w ramach każdego rejonu w obwodzie grodzieńskim; w drugim etapie udział biorą zakwalifikowani na podstawie wyników pierwszego etapu twórcy ludowi i tradycyjne zespoły muzyczne; w ramach trzeciego etapu, ocenianego przez jury, zostają wyłonieni laureaci w kilkunastu kategoriach.

${ }^{8}$ Co druga doroczna edycja festiwalu odbywa się w Białymstoku. Nagrania z poszczególnych edycji znajdują się w Archiwum Fonograficznym IS PAN.
} 
kultury ludowej i repertuaru na terenie Grodzieńszczyzny. Były to osoby urodzone w latach 1927-1958, przeważnie kobiety, większość z nich miała wykształcenie średnie zawodowe, kilka osób skończyło tylko czery klasy szkoły średniej, część miała wyższe wykształcenie. Większość rozmówców nie miała formalnej edukacji muzycznej, kilka osób ukończyło muzyczną szkołę pierwszego stopnia, 3 osoby posiadały dyplom szkoły muzycznej drugiego stopnia (bądź muzycznych kursów podyplomowych), większość nie znała pisma nutowego, kilka osób znało nuty, a niektóre potrafiły zagrać/zaśpiewać z nut. Wszystkich rozmówców łączy deklarowana przynależność do grupy Polaków mieszkających na Grodzieńszczyźnie oraz „zawód”9 muzykanta/śpiewaka ludowego.

\section{Świat tradycyjnej kultury muzycznej mniejszości polskiej na Grodzieńszczyźnie}

Świat muzyczny, z jakim zetknęłam się na Grodzieńszczyźnie, przedstawia się dwojako. Z jednej strony jest to świat pamiętany w takiej postaci, jaką miał kiedyś - w okresie dwóch powojennych dekad. $Z$ drugiej strony - obok świata wspomnień funkcjonuje współczesny świat muzyczny, na którym swoje piętno odciskają upodobania wykonawców, ich percepcja odbioru i prezentowania muzyki, wzorce zaczerpnięte z mediów. Te dwa światy funkcjonują dzisiaj niezależnie od siebie, $\mathrm{z}$ tendencją do kurczenia się pierwszego z nich i stopniowego poszerzania się grona odbiorców tego drugiego.

Pamiętany świat muzyczny nie ma przełożenia na współczesny obieg kultury, jego „żywotność” jest ściśle powiązana z żyjącymi jeszcze ludźmi, którzy przechowują niegdysiejsze obyczaje, teksty czy melodie. Do tego świata należy większość obrzędów dorocznych i rodzinnych wraz z powiązanymi z nimi pieśniami i muzyką, której różnorodność podlega jednak stałej redukcji ze względu na brak użyteczności. Podobnie pieśni powszechne, które wraz z zanikiem tradycji spontanicznego śpiewania odgrywają coraz mniejszą rolę w życiu codziennym, a także podczas świąt.

Repertuar z przeszłości ma dla wykonawców znaczenie emocjonalne, symboliczne i przywoływany jest podczas występów na przeglądach twórczości ludowej. Sporadycznie przenika też do świata rzeczywistego, wypełniając emocjonalną niszę związaną z poczuciem więzi z Polską, potrzeby odwoływania się do znanych z dzieciństwa symboli: flagi, godła, modlitw ${ }^{10}$. Ważne znaczenie dla wykonawców mają także pieśni śpiewane kiedyś przez ich rodziców - w okresie prześladowań religijnych (Mikhailik 2008: 215-251) oraz

\footnotetext{
${ }^{9}$ Nie używam terminu „zawód” w znaczeniu zajęcia, którego ktoś się wyuczył i wykonuje w celach zarobkowych, lecz w znaczeniu pełnienia konkretnej roli (muzykanta/śpiewaka) w sytuacjach muzycznych życia społeczności, co w literaturze etnomuzykologicznej i popularno-naukowej jest określane jako „zawód" (Dahlig 1993; Bieńkowski 2001).

${ }^{10}$ Obie kategorie ,pochodzenie” i ,narodowość” były określane przez rozmówców jako polskie.
} 
przesiedleń etnicznych (Mironowicz 2007: 229-235). Wykonawcy również dzisiaj mogą czuć się dyskryminowani, dostrzegają analogie między swoją ówczesną sytuacją a współczesnością. Przywołują z pamięci te pieśni, które lata temu stanowiły wsparcie, łączyły społeczność w duchu narodowym. Teraz także mają one służyć walce o zachowanie własnej tożsamości. Neutralne narodowo pieśni - weselne, chrzcinowe, dziecięce oraz rozmaite obrzędowe z cyklu dorocznego - wraz z utratą funkcji użytkowej w nowej rzeczywistości tracą aktualność, pozostając wyłącznie w domenie wspomnień.

Młode pokolenie pozostaje jednak depozytariuszem dawnego świata muzycznego ${ }^{11}$. Mimo że wykonawcy tej generacji nie doświadczyli tamtego, minionego świata bezpośrednio, przyswoili go jednak dzięki książkom i opowieściom. Olbrzymią rolę w przekazaniu tradycji oraz stworzeniu możliwości do ich poznania odegrał kościół rzymskokatolicki oraz polskie placówki oświatowo-edukacyjne. $\mathrm{W}$ ostatnich latach organizatorzy rejonowych oraz obwodowych konkursów i festiwali muzycznych kładą większy nacisk na prezentowanie miejscowego repertuaru ludowego w formie „niestylizowanej”, co jest podkreślane w regulaminach konkursowych (ROFFR 2017). Miejscowe zespoły czerpią repertuar z różnego rodzaju publikacji, nagrań oryginalnych wydanych na płytach $\mathrm{CD}$, z prywatnych archiwów kierowników zespołów. Dzisiaj, na fali ruchu revival ${ }^{12}-\mathrm{m}$.in. w ramach działalności domów kultury, tradycyjny repertuar pojawia się na lokalnych scenach nieco częściej. Warto tu zaznaczyć, że tendencja odejścia od „przetworzonego” folkloru muzycznego na rzecz możliwie jak najwierniejszego odtwarzania, sprzyja powstawaniu zespołów o charakterze rekonstrukcyjnym. Członkami zespołów są w szczególności młodzi ludzie, znajdujący się pod opieką instruktorów i specjalistów w dziedzinie folkloru. W ramach działań zrekonstruowano takie obrzędy, jak „Wołanie wiosny”, „Kolędowania” („Kaliadki”), „Bogacz” („Bahacz”) oraz „Wałokannie” (kolędowania wielkanocne), odtworzone zostały też m.in. zapomniane tańce użytkowe: pogirska kadryl (rejon zdzięcielski), tudarowska kadryl (rejon korelicki). Na listę historyczno-kulturowych wartości Republiki Białorusi trafiły m.in. tradycja „,rozpisywania” wielkanocnych jajek (Sapoćkinie), twórczość mistrza Mariana Skramblewicza związana z budową instrumentów muzycznych (Odelsk) oraz twórczość mistrzyni Aleny Szuniejki z Grodna, zajmującej się wyrobem tradycyjnych gobelinów techniką pierabornaha oraz podwójnego jednostronnego tkactwa (GOKW).

Mimo zauważalnych, wspomnianych wyżej tendencji, stanowią one jednak niewielki procent dzisiejszych praktyk artystycznych. Folklor muzyczny (głównie tekst, rzadko melodia), a także obrzędy często stanowią jedynie materiał do dalszego przetwarzania

\footnotetext{
${ }^{11} \mathrm{Na}$ podstawie badań ankietowych oraz wywiadów prowadzonych przeze mnie w latach 2014-2017 wśród młodzieży szkolnej oraz zespołów folklorystycznych w obwodzie grodzieńskim.

${ }^{12}$ Revival - zjawisko rewitalizacji zanikających gatunków muzycznych (zob. Livingston 1999: 66-85).
} 
w formie właściwej dla muzyki popularnej bądź rozrywkowej. W ten sposób powstają rozmaite fuzje stylistyczne, niestety często wątpliwej jakości. Muzyczny świat rzeczywisty jest związany z otaczającymi moich rozmówców, zmieniającymi się realiami. W ciągu ostatnich 20 lat tempo tych przemian jeszcze przyspieszyło. Można wskazać tu szereg kluczowych czynników: oddziaływanie stolicy obwodu - Grodna, urbanizację, radio i telewizję, bezpośrednie sąsiedztwo rejonu grodzieńskiego z Polską i związany z tym zwiększony ruch przygraniczny, wymianę i wzajemne wpływy, wyjazdy i migracje, a także bogacenie się społeczności. Czynniki te wpłynęły i wciąż wpływają na postrzeganie własnej kultury oraz jej obraz na zewnątrz. W przypadku osób młodych $\mathrm{i}$ tych $\mathrm{w}$ wieku średnim dodatkowy wpływ ma Internet i nowe media.

Należy zaznaczyć, że polskojęzyczny repertuar jest w niewielkim stopniu uwzględniany w ofercie artystycznej Grodzieńszczyzny. Przeglądając programy konkursów folklorystycznych ${ }^{13}$ za lata 1997-2001 muszę stwierdzić, że polskojęzyczne pieśni stanowiły zaledwie ok. 4 proc. całości programu. Taka sytuacja świadczy o fragmentarycznym podejściu do prezentowania bogactwa kulturowego rejonu Grodzieńszczyzny i tendencji zanikania pewnych obszarów repertuaru muzycznego. Niewątpliwie zagadnienie to wymaga dłuższych obserwacji i analiz w celu przeprowadzenia oceny kierunku rozwoju prezentacji poszczególnych tradycji lokalnych oraz ewentualnego zaprojektowania przyszłościowych rozwiązań edukacyjno-kulturalnych.

Współczesnym przykładem zespołu folklorystycznego, wykorzystującego polski i białoruski repertuar (w tym także miejscowego pochodzenia), może być grupa Lechici z Grodna. Całość jej programu stanowi ponad sto utworów ludowych w opracowaniu, inscenizacje obrzędów bądź ich części, a także tańce. Jak opowiada kierowniczka zespołu, Regina Zawadzka:

W Grodnie mieszkają liudzie, które ze wsi przyjechali. Ja nawet folklior czasem zbieram nie na
wsi, a w tych mieszkaniach [w Grodnie]. Wesele z okolic Grodzieńszczyzny, to chodziłam - taka
przyczółka jest, dzielnica w Grodnie - to tam zbierałam czasem. Mówili: W takim a takim miesz-
kaniu mieszka taka a taka pani, ona bardzo dobrze śpiewa. Tam chodziłam i oni śpiewali. Tak było.

Z moich obserwacji wynika, że na dobór repertuaru wpływają zasadniczo dwa czynniki: wiek wykonawców oraz działalność koncertowa. Są one ze sobą związane, jednak nie warunkują się wzajemnie. Im młodszy jest artysta, tym bardziej ,współczesny” jest jego repertuar. Z kolei działalność koncertowa, jako forma aktywnego uczestniczenia w życiu kulturalnym rejonu czy całego kraju, kształtuje poniekąd zasób repertuaru, co opisuję poniżej. Wśród moich rozmówców byli tacy, którzy co najmniej od 20 lat nie są

\footnotetext{
${ }^{13}$ Na podstawie udostępnionych przez Rejonowe Centrum Metodyczne w Grodnie materiałów wideo.
} 
członkami żadnego zespołu czy chóru (oprócz chóru kościelnego) oraz tacy, którzy ciągle są aktywni na lokalnych, krajowych czy nawet zagranicznych scenach.

Do tej pierwszej grupy należą 4 starsze śpiewaczki ze wsi Kwasówka (urodzone w latach 1934-1941), które nie są członkiniami sformalizowanego zespołu, mają natomiast wspólny „program”, wykonywany jeszcze w czasach młodości podczas wspólnego spędzania czasu, przy pracach domowych, na zabawach. Dziś dwie trzecie ich repertuaru stanowią pieśni religijne, nazywane świętymi albo kaścielnymi (np. Kto się w opiekę odda Panu swemu). Folklor obrzędowy pamiętają słabo, a wśród pieśni powszechnych - poza nielicznymi wyjątkami polskich pieśni patriotycznych (np. Ptynie Wisła, plynie) oraz lirycznych (np. Ach, liuby Janku, jak zasmucony) - większość stanowią popularne wersje ludowych pieśni białoruskich bądź mieszczańskie romanse rosyjskie (np. Stużyt ja liotczikam).

Do drugiej grupy należą panie z zespołu Adelczanka, działającego od 2009 roku przy Centrum Kultury i Ludowych Tradycji Rejonu Grodzieńskiego we wsi Odelsk. W ich repertuarze znajdują się i polskie, i białoruskie pieśni, które wykonawczynie uznają za swoje bez różnicowania ich pod względem pochodzenia. Ponad trzy czwarte repertuaru koncertowego stanowią pieśni powszechne w języku białoruskim (np. Dziewulia maja), ukraińskim (np. Nese Halia wodu) oraz polskim (np. Wyganiała Kasia wołki), w dużej mierze popularne pieśni folklorystyczne w opracowaniu (wraz z mechanicznym podkładem muzycznym i ułożoną choreografią). Reszta repertuaru to pieśni obrzędowości rodzinnej (np. Stońce hreje, wiecier wieja; W zielionym gaiku). Jak widać, w porównaniu do poprzedniej grupy, proporcje repertuaru są w dużej mierze odmienne. $Z$ jednej strony, blisko dekada funkcjonowania w zespole i regularne występy pozwoliły na zachowanie „swojego" repertuaru sprzed lat, choćby poprzez wykorzystanie go do prezentowania się podczas występów. $Z$ drugiej strony, osobisty repertuar każdego z członków wzbogacił się o nowe pieśni, jak podkreślały same śpiewaczki, dzięki wymianie doświadczeń i wiedzy między członkami zespołu, mającymi różne doświadczenia muzyczne.

Prowadząc badania wśród członków formalnie funkcjonującego zespołu ludowego, badacz musi jednak zdawać sobie sprawę z pewnego ryzyka. Stają przed nim przede wszystkim artyści, dla których również badacz jest publicznością, taką samą jak ta na sali. Dlatego rozmówczynie odruchowo prezentowały swój koncertowy repertuar. Odstąpienie od zazwyczaj wykonywanego repertuaru - np. wskutek prośby o przypomnienie pieśni dziecięcych - przyniosło pewne rezultaty (nagrania kołysanek i zabaw dziecięcych - np. A-a, a-a, kotki dwa; Andza, dzwandza). Z kolei na prośbę o zaśpiewanie ulubionej pieśni spoza repertuaru koncertowego, śpiewaczki zaprezentowały kolejno radzieckie pieśni lat sześćdziesiątych XX wieku: Sorwal ja cwietok poliewoj (sł. Siergiej 
Smirnow, muz. Boris Makrousow), Landyszy (sł. Olga Fadiejewa, muz. Oskar Felzman), Dzieriewieńka moja (sł. Majrbiek Chajdarow, muz. Dawid Tuchmanow), Ogniej tak mnogo zolotych (sł. Nikołaj Dorizo, muz. Kiril Molczanow). Powodzeniem wśród śpiewaczek cieszyły się także mieszczańskie romanse (np. Na solnce cylinder swierkajet), których wykonywanie „na zewnątrz” one same jednak świadomie ograniczały. Przyczyną mogła być świadomość niskiej oceny tego typu repertuaru przez jurorów w konkursach i chęć zapobieżenia analogicznej reakcji ze strony badaczki.

Tradycje muzyczne na Grodzieńszczyźnie, podobnie jak i w całym kraju, odgrywają dziś niewielką rolę w życiu społeczności. Niewątpliwie obecna polityka kulturalna wpływa na ten stan rzeczy: z jednej strony, nastawiona jest na zabezpieczenie muzycznej obsługi festynów i wypełnianie normy koncertowej; kształtuje też wizerunek kulturalny Grodzieńszczyzny oraz rodzi zapotrzebowanie na taki, a nie inny rodzaj prezentacji. Z drugiej strony, przeciwstawne postrzeganie określeń „białoruski” - „polski” tworzy nierówną płaszczyznę funkcjonowania wielonarodowej muzycznej kultury.

Badając kulturę muzyczną polskiej społeczności na Grodzieńszczyźnie, postanowiłam dotrzeć do jej obrazu funkcjonującego w świadomości moich rozmówców. W tym celu w trakcie wywiadów z rozmówcami starszego pokolenia zastosowałam metodę ankiety dźwiękowej, opartej na założeniach opracowanych przez Sławomirę Żerańską-Kominek.

\section{Badania nad świadomością etnomuzyczną mniejszości polskiej}

Podstawą badań nad świadomością etnomuzyczną jest założenie, że każdy członek określonej grupy posiada intuicyjną kompetencję muzyczną, pozwalającą na spontaniczną identyfikację rodzimego stylu, poprawności i zgodności z istniejącym idiomem - wzorcem wewnętrznej organizacji struktury muzycznej. W zakresie kompetencji muzycznych ciekawe eksperymenty prowadziła białoruska etnomuzykolog Zinaida Możejko (Mozheǐko 1985: 63-70). Dla zbadania rozpoznawalności pieśni obrzędowych i ich gatunkowej typizacji, a następnie rozpoznania zależności oceny estetycznej od jej gatunkowej przynależności, zastosowała ona takie narzędzie badawcze, jak „zwuczaszczaja ankieta”. Na podstawie uzyskanych wyników badaczka wskazała gatunki od najbardziej do najmniej rozpoznawalnych przez uczestników eksperymentu - ludowych muzykantów, a także nakreśliła korelację pomiędzy oceną estetyczną pieśni a prawidłowym ich zaklasyfikowaniem.

Wśród polskich etnomuzykologów problemem świadomości etnomuzycznej zajęła się Sławomira Żerańska-Kominek (1990: 13-97). Teoretyczną podstawą jej badań była definicja grupy etnicznej oparta na wewnętrznych kategoriach poczucia przynależności 
do danej grupy (Obrębski 1936: 3-5; Barth 1969: 13-14). Dostrzeżono, że problematyka własnego wizerunku grupy etnicznej jest analogiczna do zagadnień związanych z autowizerunkiem etnomuzycznym, a podział na członków i nie-członków grupy (s woich i obcych) w podobny sposób przejawia się w sferze muzyki. Ponieważ w kulturze ludowej własny styl muzyczny nie jest uświadamiany przez grupę (Blacking 1983), badacz może pokusić się o skonstruowanie etnomuzycznego wizerunku grupy poprzez konfrontację grupy z muzyką obcą. Otóż, w wyniku zetknięcia się z muzyką obcego powstaje stereotyp obcości w muzyce, „który stanowi negatywną i wyolbrzymioną projekcję kilku najważniejszych cech determinujących poczucie obcości w muzyce". Żerańska-Kominek wyprowadza z tego bardzo ważną wykładnię: ,,wizerunek własnego stylu muzycznego jest odwróconym obrazem (wizerunku) stylu obcego" (Żerańska-Kominek 1990: 71). Obraz ten funkcjonuje w postaci zwerbalizowanego idiomu muzycznego, na który składa się zbiór najważniejszych dystynktywnych cech danego stylu.

Wyniki badań prowadzonych przez S. Żerańską-Kominek wśród Litwinów w północno-wschodniej Polsce potwierdziły hipotezę dużego stopnia identyfikacji z rodzimym stylem. Oprócz analizy statystycznej, dokonano wówczas także analizy komentarzy pozawerbalnych $\mathrm{w}$ celu określenia stereotypu grupy obcej w świadomości badanych. Kilka lat później metodę tę zastosowała Anna Szewczuk-Czech w swoich badaniach nad świadomością etnomuzyczną ludności białorusko- oraz ukraińskojęzycznej Podlasia (Szewczuk-Czech 1996).

W celu określenia (zidentyfikowania) autowizerunku muzycznego polskiej mniejszości w rejonie grodzieńskim również zastosowałam kwestionariusz muzyczny bazujący na założeniach opisanych przez S. Żerańską-Kominek. Moim celem było zdefiniowanie odmiennych idiomów stylistycznych istniejących w świadomości badanej grupy. Następnie zaś, poprzez wyartykułowanie przez informatorów różnicy między obcym a własnym stylem, udało się zarejestrować autowizerunek muzyczny badanej grupy. Narzędziem badawczym stał się kwestionariusz muzyczny, zawierający pieśni i muzykę instrumentalną: 1) tożsamą z miejscowym repertuarem, 2) częściowo mającą wspólne cechy z repertuarem badanego obszaru oraz 3) odległą terytorialnie i najmniej pokrewną stylistycznie muzykę tradycyjną. Eksperyment zakładał odnotowanie najwyższego stopnia bliskości z którymś z zawartych w wymienionych wyżej grupach repertuarów, co oznaczałoby identyfikację z danym stylem muzycznym. Założenie dotyczyło polskojęzycznego repertuaru z Poniemnia oraz pobliskich terenów. 
Mój kwestionariusz muzyczny składał się z 15 przykładów muzycznych (dziesięciu wokalnych, jednego wokalno-instrumentalnego oraz czterech instrumentalnych ${ }^{14}$ ), trwających około 30 sekund każdy. Siedem pieśni i jeden utwór instrumentalny pochodził z Grodzieńszczyzny (rejony szczuczyński, zdzięcielski, werenowski) i stanowił przykład typowy dla białoruskiej tradycji Poniemnia ${ }^{15}$. Jedna pieśn, wokalno-instrumentalny utwór oraz melodia taneczna pochodziły z terenu Wielkopolski i Mazowsza - najbardziej oddalonych od badanego obszaru - i zawierały typowe cechy polskiego folkloru muzycznego. Trzy pieśni w języku białoruskim i jeden utwór instrumentalny pochodziły z Podlasia (województwo lubelskie oraz mazowieckie). A więc dobrane przykłady dźwiękowe reprezentują 4 różne regiony etnograficzne, przy czym w przypadku Poniemnia i Podlasia został przedstawiony białorusko- oraz polskojęzyczny repertuar.

Prezentacja kwestionariusza polegała na emitowaniu krótkich fragmentów słuchaczom, po czym byli oni proszeni o odpowiedź na następujące pytania: 1) czy słuchaczowi znana jest ta pieśń (melodia instrumentalna)?; 2) czy ta pieśń (melodia instrumentalna) jest miejscowa?; 3) czy słuchaczowi podoba się ta pieśń (melodia instrumentalna)? Tą metodą przebadanych zostało piętnaście osób (trzech mężczyzn i dwanaście kobiet) - mieszkańców rejonu grodzieńskiego, określających się jako Polacy. Urodzeni w latach 1929-1948, o różnym doświadczeniu muzycznym i edukacji ogólnej, wszyscy byli - bądź wciąż są - aktywnymi muzykantami/śpiewakami ludowymi.

Osoby słuchające wcześniej przygotowanego zestawu dźwiękowego w sposób, można by powiedzieć, podświadomy określały werbalnie poprawność bądź niepoprawność danego stylu muzycznego, a nawet jego cech (jak barwa głosu, maniera wykonania). Często prosiłam respondentów o komentarz do wysłuchanej pieśni czy melodii instrumentalnej, co ankietowani chętnie robili. Komentarze, niekiedy bardzo obszerne, oraz pozawerbalne formy wyrażania stosunku do przedstawianych pieśni i muzyki tanecznej posłużyły za podstawę do analizy semantycznej, a także próby sformułowania wizerunku kultury muzycznej funkcjonującej w świadomości społeczności polskiej na badanym

\footnotetext{
${ }^{14} \mathrm{~W}$ dotychczasowych badaniach prowadzonych przy zastosowaniu tej metody nie uwzględniono muzyki instrumentalnej. Postanowiłam włączyć do „pytań” muzykę instrumentalną, aby sprawdzić stopień swojskości bądź obcości rytmów dwumiarowych stabilnych oraz trójmiarowych w tempie rubato. Poza tym muzyka bez tekstu słownego kieruje całą uwagę słuchacza na takie elementy muzyczne, jak tempo, barwa instrumentu, sposób wykonania, możliwość zatańczenia do tej melodii, czyli elementów pozawerbalnych.

${ }^{15}$ Poniemnie jest jednym z pięciu regionów muzyczno-etnograficznych Białorusi, pozostałe to: Pojezierze, Przydnieprze, Centralna Białoruś i Polesie (Wschodnie i Zachodnie). Granice tych regionów w dużym stopniu pokrywają się z podziałem administracyjnym kraju - odpowiednio obwodami: grodzieńskim, witebskim, mohylewskim, mińskim, brzeskim i homelskim (przy czym dwa ostatnie składają się na region Polesia). Każdy z tych regionów posiada odmienne cechy folkloru muzycznego i tradycji ludowych. Zob.: Možejko 1985; Varfalameeva 1998; TMKB 2006.
} 
obszarze. Należy zaznaczyć, że badania te mają wybitnie jakościowy charakter, stąd wybór tylko jednego rodzaju analizy.

Na podstawie odpowiedzi na pytania oraz zachowań niewerbalnych można stwierdzić, że żaden z zasłyszanych stylów reprezentujących jeden z czterech regionów etnograficznych, nie został w całości uznany przez respondentów za swój. Nie potwierdziło się także hipotetyczne założenie o wysokim stopniu identyfikacji ankietowanych z polskojęzycznym repertuarem pochodzącym z sąsiednich regionów. Co ciekawe, żaden z prezentowanych regionów etnograficznych nie został w całości określony także jako ob cy. Świadczyć to może o dosyć rozmytym obrazie etnomuzycznym badanej grupy, stanowiącym przeplatankę cech białoruskiego folkloru Poniemnia oraz polskich tradycji zakorzenionych na danym obszarze. Powstała na tej bazie nowa jakość rządzi się własnymi prawami, których zbadanie wymaga dalszych obserwacji.

W trakcie moich badań obca muzyka spotykała się z natychmiastową reakcją, co potwierdza przyjęte na początku założenie o spontaniczności i intuicyjności identyfikacji muzyki własnej. Styl obcy zawsze był określany mianem „,nie nasza”, często na zmianę z określeniem „biełaruskaja”, „niejkaja biełaruskaja”. Znajdujące się na dwóch różnych biegunach określenia „nasza” i „biełaruskaja” wyrażały także szersze wypowiedzi o charakterze analitycznym:

U nas inakszy akcent, a u ich inakszy akcent. My możam daże zaśpiawać pa etomu, a u nas akcent druhi. - A jaki u was? - Nu, wo, bolieje... Jak u nas adna u kaściele śpiawaje tak: U-o! [śpiewa wysoko, falsetem] Tam [na nagraniu] na krzyk...i tak ciahnuć, a my chutczej śpiawajem. U nas tak nie ciahnuć tak [pokazuje jak]. A jany tak zaciahwajuć.

(wieś Odelsk, kobieta, ur. 1929)

Ot! To takie: e-e-e, wot to, Pani słyszała, to ja nazywam zaciągnięciem. Ot, te według mnie jest bardzo charakterystyczne dla tutejszych Biełarusinów.

(miasto Grodno, kobieta, ur. 1940)

Poprzez negację obcego stylu rozmówcy potrafili wyartykułować także własny styl:

Jany inaczej śpiawajuć jak my. My nie ciahniem tak. [...] u nas ksiądz i to każa: Nie ciahnijcie! U nas, u kaściole, chyba inaczej śpiawajuć.

(wieś Odelsk, kobieta, ur. 1929)

Krzyk [w odniesieniu do zasłyszanego nagrania w języku białoruskim z Poniemnia]. A u nas bardziej gowor. My takija zusim nie śpiawajem. 
Kolejną opozycją cech składających się na wizerunki obcego i swojego jest para: „krzyk” i ,inteligencja”. Określenia te wiążą się także ze sposobem bycia, który ma bezpośredni wpływ na tworzoną kulturę muzyczną.

Zależy od tego, od kogo pochodzą te piosenki. Są białoruskie piosenki, które mogą taki dźwięk mieć okrągły, jeżeli to inteligencja. Inteligencja krzyczeć nie budzie. To ona coś ma innego w sobie niż prosty naród.

(miasto Grodno, kobieta, ok. 55 lat)

Świadomość nietutejszości odmiennego stylu nie przeszkadzała jednak ankietowanym w uznaniu walorów artystycznych twórczości.

Nie... to pa biełarusku śpiawajuć... ale ż krasiwo jany śpiawajuć. Dobra.

(wieś Kwasówka, rejon grodzieński, kobieta, ur. 1941)

O, na głosy! Dobrze śpiewaje. To już po białorusku. Teraz tego nie śpiewają. To jest ludowe śpiewanie, ludowe głosy.

(miasto Grodno, kobieta, ur. 1932)

Idiom „głosu ludowego" w większości ma konotacje narodowościowe, tzn. Białorusinom była przypisywana umiejętność śpiewania „na ludowo”. W stosunku do polskojęzycznych pieśni z kwestionariusza tylko raz użyto sformułowania „ludowy głos”. Ważne jest to, że idiom „polski” jest pojęciem przestrzennym. W miejscowej tradycji jest on zwerbalizowanym poczuciem swojskości wobec „białoruskiego”. Jednak gdy perspektywa oceny się rozszerza, ,polski” przede wszystkim oznacza „coś” w Polsce, a dopiero później na Białorusi.

O, to typiczne polskie. Dla tych kresowych.

(miasto Grodno, kobieta, ur. 1940)

Eta u Polszczy, kalia Sokółki baby śpiewają.

(wieś Odelsk, rejon grodzieński, kobieta, ur. 1927)

Inną kwestią jest śpiewanie na głosy, które, jak słychać w komentarzach badanych, wiąże się z tradycją obcą.

Wedlug mnie, to chyba na jeden głos tu śpiewano. [...] Białorusini śpiewają na głosy.

(wieś Odelsk, rejon grodzieński, kobieta, ur. 1940)

Reakcje i komentarze dotyczące muzyki instrumentalnej dają bardzo ciekawy obraz funkcjonowania instrumentów muzycznych w kulturze miejscowej lub polskiej na Białorusi. Otóż cymbały nie są odbierane jako instrument ludowy, lecz zaliczane do 
współczesnego instrumentarium profesjonalnego, co zapewne jest związane z rozpowszechnioną praktyką gry na tym instrumencie na wszystkich szczeblach edukacji muzycznej na Białorusi. Brzmienie dud wielkopolskich nie jest rozpoznawane w ogóle, a respondenci przypuszczali, że ten instrument nie jest polski. Wśród tańców polka była identyfikowana bardzo szybko. Oberki były uznawane za polskie, czyli swoje, ale tylko te wykonywane na harmonii określano jako oberki.

Spośród pieśni obrzędowych identyfikowane były pieśni wielkanocne, których refreny (Ej, wino, wino, zielone) często były podchwytywane przez ankietowanych. Jednym z ważnych dla respondentów kryteriów różnicowania pieśni było kryterium językowe. Język polski w tym przypadku świadczył o pochodzeniu pieśni. Jednak pieśń śpiewana po polsku nie zawsze była uznawana za swoją, co wprowadzało informatorów w zakłopotanie. Uważam, że zachodziła reakcja typu: słyszę język polski $\rightarrow$ jest to polska pieśń $\rightarrow$ śpiewają ją Polacy $\rightarrow$ jestem Polakiem $\rightarrow$ ale nie jest to nasza pieśń $\rightarrow$ jestem innym Polakiem. Świadomość swojej odrębności jako grupy potwierdza się także w komentarzach na temat własnej polskości ${ }^{16}$ : ,„[... my to takija - horszyja paliaki, a tam wo [w Polsce] praŭdziwyja".

Analiza zebranych materiałów pozwoliła mi na wyszczególnienie kilku cech składających się na wyobrażenie muzycznej kultury swojej i obcej przez przedstawicieli badanej grupy.

1. „Polska” kultura muzyczna = bardziej swoja ( poziom deklaracji $)=$ akceptacja. Cechy: wyższy status; język polski, mieszany język (polsko-białoruski); „,spokojny”, „łagodny”, ,akademicki” śpiew; przewaga wykorzystania głowowego rejestru. Chóry (świeckie, ludowe, kościelne, zespoły z kierownikiem). Unisono. Rubato. Repertuar doroczny: kolędy, pieśni wielkanocne (wołokajne), pieśni dożynkowe. Cyk1 rodzinny: pieśni weselne, pogrzebowe, kołysanki. Repertuar powszechny: ballady, miłosne, harcerskie, patriotyczne, żołnierskie, partyzanckie, biesiadne, przyśpiewki do tańca, „folklor grodzieński”, ballady miejskie. Repertuar religijny, kościelny - ma szczególne znaczenie.

2. „Białoruska” kultura muzyczna = bardziej obca $($ poziom deklaracji) = niski stopień akceptacji. Cechy: język białoruski, mieszany język (polsko-białoruski, rosyjsko-białoruski), rosyjski język. Wielogłos (dwugłos, sporadyczny trzygłos). Sposób śpiewania: „ludowy”, „wiejski”. Szerokie śpiewanie samogłosek, donośny śpiew, piersiowy rejestr, „krzykliwy”. Stabilne metrum, brak swobody poruszania się wewnątrz taktów. Repertuar doroczny: pieśni wielkanocne, pieśni dożynkowe. Cyk1

\footnotetext{
${ }^{16}$ Dostrzeganie różnic przez samych wykonawców pomiędzy polskimi pieśniami śpiewanymi na Białorusi a pieśniami z Polski potwierdza Renata Banasińska w swoich badaniach nad repertuarem pieśniowym mieszkańców rejonów lidzkiego i werenowskiego na Grodzieńszczyźnie. Zob. Banasińska 1998: 36-37.
} 
rodzinny: wesele, pogrzeb, kołysanki, dziecięce. Repertuar powszechny: ballady, miłosne, przyśpiewki do tańca, frywolne, mieszczański romans.

Wyniki kwestionariusza muzycznego w konfrontacji z wykonywanym przez respondentów repertuarem muzycznym, nagranym podczas badań terenowych, przedstawiają się jeszcze inaczej. Na poziomie realizacji wyróżnione cechy płynnie przechodziły $\mathrm{z}$ jednej grupy stylistycznej do drugiej, co wydaje się, było uwarunkowane nie tylko poczuciem estetycznym wykonawców, doświadczeniem muzycznym i ich usposobieniem wobec prezentowanego repertuaru, ale także indywidualnymi możliwościami wykonawczymi. Tak np. wykonywany zespołowo repertuar weselny był prezentowany w dwugłosie, powszechne było wykorzystanie „ludowej” emisji o wzmożonym natężeniu w repertuarze religijnym śpiewanym po polsku.

Zastosowanie ankiety dźwiękowej w badaniach nad pograniczem kulturowym, jakim jest obszar Grodzieńszczyzny, jest bardzo dobrym narzędziem do badań nad autowizerunkiem muzycznym określonej grupy społecznej. Wyniki ankiety oraz muzyczna analiza właściwego repertuaru własnego badanej grupy, dają podstawę do myślenia o specyficznym i odrębnym wizerunku kultury muzycznej społeczności polskiej na Grodzieńszczyźnie. Wpisując się w ogólną tradycję muzyczno-etnograficzną Poniemnia, wszystkie cechy są nieco rozmyte, zatarte, brak w nich definitywnych tropów. Nie jest to ani białoruska kultura grodzieńskiego Poniemnia, ani też macierzysta polska kultura w postaci spotykanej na terytorium Polski. Wymowna jest pewna prawidłowość: gdy na koniec wywiadu prosiłam respondentów o zaśpiewanie swojej ulubionej pieśni, najczęściej słyszałam któryś z popularnych w latach sześćdziesiątych - osiemdziesiątych XX wieku szlagierów rosyjskich. Jednak wydaje się, że kreowanie autowizerunku muzycznego jest jednym z najistotniejszych elementów podkreślenia swojej „polskości” przez badaną grupę.

\section{Zakończenie}

Repertuar Polaków na Grodzieńszczyźnie ulega ciągłym zmianom. Maleje zasób repertuarowy osób starszych, śpiewane niegdyś pieśni idą w zapomnienie, depozytariusze pieśni odchodzą. Przede wszystkim w obszarze muzyki instrumentalnej dokonała się olbrzymia redukcja i dzisiaj jest to obszar najsłabiej reprezentowany. Współczesny repertuar starszego pokolenia, jak pokazały wstępne badania, w większości składa się z repertuaru religijnego. Z kolei jego dużą część stanowią szlagiery okresu radzieckiego (takie preferencje mają zwłaszcza starsi rozmówcy). Wśród polskich pieśni (pomijając sferę religijności) istotną rolę odgrywają pieśni patriotyczne, podobnie dosyć często mamy do czynienia z polskojęzycznymi utworami radiowymi. W tych ostatnich gustują osoby 
młode, czego dobitnym dowodem są wyniki badań ankietowych przeprowadzonych przeze mnie w 2013 roku wśród uczniów Polskiej Macierzy Szkolnej w Grodnie (Niakrasava 2015b).

Nieco inaczej ma się sprawa z członkami zespołów folklorystycznych. Ich repertuar jest bogatszy ze względu na kilka czynników. Po pierwsze, praktykują i pielęgnują posiadany repertuar. Uzupełniają go o nowe pieśni, m.in. usłyszane i przywiezione z Polski. Mają też częstszy kontakt z Polską i jej kulturą, bo tam występują. Z drugiej jednak strony, na Białorusi - jak wynika ze wstępnego zapoznania się z programami konkursów i festiwali - rzadko prezentują oni polskojęzyczny repertuar. Poszerzeniu repertuaru sprzyja też różnorodność stylistyki: od opracowań pieśni i muzyki tradycyjnej po rekonstrukcję, która znalazła się obecnie w obszarze zainteresowań młodzieży, biorącej udział w działalności zespołów folklorystycznych.

Świat muzyczny moich respondentów przedstawiał się dwojako: z jednej strony, to świat pamiętany, z drugiej - rzeczywisty. Niewątpliwie, więcej polskich pieśni znalazło się po stronie odchodzącego świata pamiętanego. Brak utożsamiania się z tradycjami polskiej czy białoruskiej kultury może świadczyć o specyficznym podwójnym funkcjonowaniu obu kultur w świadomości polskiej społeczności. Zmieniająca się dookoła rzeczywistość w przyspieszonym tempie wpływa na repertuar badanej grupy, a przede wszystkim na miejsce, jakie zajmuje muzyka w ich życiu, oraz na sposoby uczestniczenia w kulturze.

Wyniki wstępnych badań pozwalają stwierdzić, że dla Polaków żyjących na Białorusi polska kultura wiąże się ze swoistym wyższym statusem społecznym. Wielu z respondentów miało też poczucie zagubienia, co odzwierciedla przytoczona przez jedną z moich rozmówczyń wypowiedź jej wnuka, obecnie studiującego w Polsce: „Chcę Pani powiedzieć, że Janek - starszy toj [wnuk], on na czwartym roku jest, to on mówi: «Babcia, wiesz, nas tam nie liubią. Tu nas nazywają paliakami, a tam nas ruskimi nazywają». O jak my żyjemy, kochani moi”. Właśnie w takich konfrontacjach z rzeczywistością w Polsce pojawia się refleksja dotycząca odmienności etnomuzycznego wizerunku badanej grupy, dzięki której podkreślane jest (bądź nie podkreślane) własne poczucie „polskości”. Świadomość różnicy między Polakiem z prawej strony Bugu - na ogół gorszym w odczuciu moich informatorów - a Polakiem z Polski jest dosyć powszechna. Nierzadko towarzyszy jej poczucie żalu do Wielkiej Ojczyzny o zapominanie o rodakach żyjących tuż za granicą kraju. „Kocham Polskę, kocham Polaków, ale Polska mnie skrzywdziła. Nikt nie zainteresował się, czy zespół nasz działa czy nie, nikt mi nie podziękował" - skarżyła się w rozmowie ze mną jedna z byłych kierowniczek zespołu z polskojęzycznym repertuarem. 
To „pęknięcie” między białoruskimi Polakami a ich ojczyzną, mogłoby stanowić temat osobnych, szeroko zakrojonych badań. Wzmaga je fakt, że modernizacja mediów publicznych w Polsce - w szczególności przejście na emisję sygnału cyfrowego przez stacje telewizyjne - doprowadziło do odcięcia białoruskich Polaków od najważniejszego źródła informacji, m.in. kulturalnych, znad Wisły (rzadko kiedy Polacy na Białorusi mogą sobie pozwolić na dekodery umożliwiające odbiór takiego sygnału). W efekcie jedną z nielicznych polskich stacji, jakie można jeszcze powszechnie odbierać na Grodzieńszczyźnie, pozostaje Radio Maryja - co skądinąd współgra z wysiłkami Kościoła katolickiego na Grodzieńszczyźnie, który nadal odgrywa ważną rolę w podtrzymywaniu „ducha polskości” wiernych. Trudno nie wiązać tych czynników ze wspomnianą wyżej popularnością repertuaru religijnego, zwłaszcza wśród osób starszych, które postrzegają pieśni te jako największą ostoję bycia Polakiem.

Trzeba jednak podkreślić, że w ostatnich dekadach częściej i na większą skalę prowadzi się działania nastawione na wsparcie mniejszości etnicznych i narodowych, zacieśnianie ich więzi z krajami „ojczystymi”, również w krajach postsowieckich. Mam na myśli „wymianę kulturalną” - organizowanie występów zespołów z Polski na Białorusi oraz zapraszanie grup z Białorusi do Polski, organizowanie warsztatów, realizowanie wspólnych projektów kulturalnych.

Według Zinaidy Możejko można wyróżnić 3 stadia funkcjonowania folkloru, w aspekcie historycznym i regionalnym (Mazheǐka ${ }^{17} 2001$ : 261-265). Pierwsze stadium to żywe funkcjonowanie. Drugie stadium to zachowanie w pamięci. Trzecie - istnienie już tylko we wcześniej zarejestrowanej postaci (transkrypcje nutowe, nagrania audio/video itp.) Moim zdaniem, tradycje kultywowane przez mniejszość polską na Białorusi wydają się znajdować w drugim stadium tego podziału. Co więcej, można się spodziewać, że najbliższe lata nie przyniosą radykalnej poprawy sytuacji - wręcz przeciwnie.

\section{Bibliografia}

Banasińska, R. (1998). Samoświadomość a repertuar pieśniowy i jego wykonanie. Z badań nad społecznościami lokalnymi Grodzieńszczyzny - rejon lidzki i woronowski. Praca magisterska pod kier. prof. dr hab. Anny Czekanowskiej. Instytut Muzykologii UW. Warszawa.

Barth, F. (1969). Ethnic Group and Boundaries. The Social Organization of Culture Difference. London: Waveland Press.

\footnotetext{
${ }^{17}$ Pisownia nazwiska różni się w zależności od języka, w jakim została opublikowana praca (rosyjski Mozheǐko albo białoruski - Mažheǐka).
} 
Blacking, J. (1983). The Concept of Identity and Folk Concepts of Self. W: A. Jacobson-Widding (ed.), Identity: Personal and Socio-Cultural (s. 47-65). New Jersey: Humanities Press.

Dahlig, P. (1993). Ludowa praktyka muzyczna w komentarzach i opiniach wykonawców w Polsce. Warszawa: Instytut Sztuki PAN.

Eberhardt, P. (1998). Polska ludność kresowa. Rodowód, liczebność, rozmieszczenie. Warszawa: PWN.

Engelking, A. (1996a). Każda nacja swoju wieru ma. Konteksty, 3/4, 177-183.

Engelking, A. (1996b). Nacje, to znaczy grupy religijne. O wynikach badań terenowych na Grodzieńszczyźnie. Kultura i Społeczeństwo, 40, 109-139.

Engelking, A. (2004). Etnograf wobec stereotypu „Polaka z Kresów”. Z przemyśleń w 10-lecie badań terenowych na Grodzieńszczyźnie. W: A. Kuczyński, M. Michalska (red.), Kultura i świadomość etniczna Polaków na Wschodzie. Tradycja i współczesność (s. 231-240). Wrocław: Wydawnictwo Uniwersytetu Wrocławskiego.

Gawin, F. (2000). Mniejszości narodowe na Grodzieńszczyźnie. Raport z monitoringu. W: Krasnogruda. Narody - Kultury - Małe Ojczyzny Europy Środkowo-Wschodniej. Pozyskano z http://pogranicze.sejny.pl/krasnogruda_nr_12_feliks_gawin mniejszosci_narodowe_na_grodzienszczyznie_raport_z_monitoringu,1311-1,12383. html.

Golachowska, E. (2012). Jak mówić do Pana Boga? Wielojęzyczność katolików na Białorusi na przełomie XX i XXI wieku. Warszawa: Instytut Slawistyki PAN, Wydawnictwo Agade.

Juzala, G. (2006). Pieśni ludowe Polaków kresów północno-wschodnich. W: P. Dahlig (red.), Folklor muzyczny w Polsce. Suplement do podręcznika Jadwigi Sobieskiej - rozwój badań 1980-2005 (s. 348-368). Warszawa: Centrum Edukacji Artystycznej.

Kabzińska, I. (1999). Wśród kościelnych Polaków. Warszawa: Instytut Archeologii i Etnologii PAN.

Kabzińska, I. (2009). Między pragnieniem ideału a rzeczywistością. Polacy na Litwie, Białorusi i Ukrainie w okresie transformacji systemowej przełomu XX i XXI stulecia. Warszawa: Zakład Wydawniczy Letter Quality.

Livingston, T. (1999). Music Revivals: Towards a General Theory. Ethnomusicology, 43, $1,66-85$.

Mazheǐka, Z. (2001). Aŭtentychny fal'klor u suchasnym svetse: shliakhi vyzhyvannia i krytychnaîa hran' zniknennia. W: V. Skalaban (red..), Historyia, kul'turalohîa, mastatstvaznaŭstva: Materyialy III Mizhnarodnaha kanhresa belarusistaŭ ,Belaruskaî kul'tura ŭ dyialohu tsyvilizatsyj” (s. 261-265). Minsk: Belaruski knihazbor. 
Mikhailik, L. (2008). Kościół katolicki na Grodzieńszczyźnie 1939-1959. Warszawa: Instytut Studiów Politycznych PAN, Oficyna Wydawnicza Rytm.

Mironowicz, E. (2007). Białoruś. Historia państw XX wieku. Warszawa: Wydawnictwo Trio.

Mozheǐko, Z. (1985). Kalendarno-pesennaia kul'tura Belorussii: opyt sistemno-tipologicheskogo issledovaniia. Minsk: Nauka i tekhnika.

Niakrasava, A. (2015a): Kultura muzyczna mniejszości polskiej na Grodzieńszczyźnie - dokumentacja historyczna a wyniki badań współczesnych. Praca magisterska pod kier. prof. dra hab. Piotra Dahliga. Instytut Muzykologii UW. Warszawa.

Niakrasava, A. (2015b). Polska kultura ludowa w świadomości społeczności polskiej na Grodzieńszczyźnie. Pozyskano z http://imit.org.pl/listit2/141/default/polskakultura-ludowa-w-swiadomosci-spolecz nosci-polskiej-na-grodzienszczynie.html.

Nowak, T. (2006). Polski folklor muzyczny Kresów Wschodnich. W: P. Dahlig (red.), Folklor muzyczny w Polsce. Suplement do podręcznika Jadwigi Sobieskiej - rozwój badań 1980-2005 (s. 317-347). Warszawa: Centrum Edukacji Artystycznej.

Obrębski, J. (1936). Problem etniczny Polesia. Sprawy Narodowościowe, t. 10, 3-35.

Szewczuk-Czech, A. (1996). Świadomość etnomuzyczna ukraińskojęzycznej ludności Podlasia. Praca magisterska pod kier. prof. dr hab. Sławomiry Żerańskiej-Kominek. Instytut Muzykologii UW. Warszawa.

Varfalameeva, T. (2006) (red.). TMKB - Tradycyjnaâ mastackaâ kultura Belarusaŭ, t. 3. Grodzenskae Panâmonne. Minsk: Vyšejšaâ škola.

Żerańska-Kominek, S. (1990). Muzyka w przemianach tradycji etnicznej Litwinów w Polsce. W: S. Żerańska-Kominek (red.), Kultura muzyczna mniejszości narodowych w Polsce. Litwini, Białorusini, Ukraińcy (s. 13-97). Warszawa: Uniwersytet Warszawski, Instytut Gospodarki Przestrzennej.

\section{Strony internetowe}

GOKW - Strona internetowa Grodzieńskiego Obwodowego Komitetu Wykonawczego. Pozyskano z http://kult.grodno-region.by/ru/narodnoe/folk.

NKSRB - Dane Narodowego Komitetu Statystycznego Republiki Białoruś (2009). Pozyskano z http://census.belstat.gov.by/default.aspx.

ROFFR - Regulamin Obwodowego Festiwalu Folkloru Regionalnego Festiwalu Folkloru Regionalnego „Poniemnia życiodajne źródła” (2017). Pozyskano z http://gromc. by/wp-content/uploads/2018/04/Polozhenie_Panyamonnya-zhyivatvornyiya -kryinitsyi_2017.pdf. 